\title{
Glycosyltransferases in the Synthesis of Oligosaccharide Analogs
}

\author{
糖転移酵素を用いたオリゴ糖類似体の合成
}

\author{
Palcic, Monica M.; and Hindsgaul, Ole \\ Department of Chemistry, University of Alberta, Edmonton, Alberta, Canada T6G 2G2, \\ FAX:403-492-7705, E-mail:Ole.Hindsgaul@Ualberta.Ca
}

Key Words: enzymatic synthesis, glycosyltransferases, oligosaccharide analogs

\begin{abstract}
The glycosyltransferase-mediated synthesis of oligosaccharide analogs is reviewed, with emphasis on the use of modified sugar-nucleotide donors or modified acceptors as substrates. A survey of the most studied enzymes: $\beta(1 \rightarrow 4)$ galactosyltransferase, $\mathrm{N}$-Acetylglucosaminyltransferase I, $\alpha(1 \rightarrow 3 / 4)$-fucosyltransferases and $\alpha(2 \rightarrow 3$ or $2 \rightarrow 6)$-sialyltransferases, shows them to be very useful for the rapid production of chemically modified di-, tri- and tetrasaccharide analogs.
\end{abstract}

\section{A. Introduction}

Recently there has been increased interest in the preparation of natural and unnatural oligosaccharide structures arising from demonstrations of their role in cellular biological recognition events (1). They serve as attachment sites for the binding of bacteria, viruses, toxins and hormones to mammalian cells, and they function in cell-cell adhesion events. Cell surface carbohydrates also change in characteristic fashion during normal and abnormal cellular development. Oligosaccharides that serve as competitive ligands therefore represent potential drug targets for the treatment of infectious diseases (2), inflammation (3-5) and cancer $(6,7)$.

While the chemical synthesis of oligosaccharides is well established, it is time consuming and requires specialized expertise (8-10). The combined chemical-enzymatic synthesis of oligosaccharides (11-16) is becoming an increasingly attractive alternative to their preparation by chemical methods alone. With the availability of an increased number of cloned glycosyltransferases (17-20) this approach will become increasingly attractive.

Mammalian oligosaccharides are biosynthesized by glycosyltransferases that catalyze the transfer of a monosaccharide from a nucleotide donor to the hydroxyl group of saccharide acceptors (21) (Fig. 1).

The most common nucleotide donors in mammalian metabolism are UDP-D-glucose (UDP-Glc), UDP- $N$-Acetyl-Dglucosamine (UDP-GlcNAc), UDP-D-galactose (UDP-Gal), UDP- $N$-acetyl-D-galactosamine (UDP-GalNAc), UDP-D-xy-

\section{要 約}

この総説では糖転移酵素によるオリゴ糖類似体の合成につ いて概観する。特に、化学修飾された糖ヌクレオチド供与体、 あるいは化学修飾された糖受容体を基質として用いたものに重 点を置いた。最もよく研究されている糖転移䤃素は $\beta(1 \rightarrow 4)$ ガラ クトース転移酵素、N-アセチルグルコサミン転移酵素 I、 $\alpha$ $(1 \rightarrow 3 / 4)$ フコース転移醅素、 $\alpha(2 \rightarrow 3)$ シアル酸転移酵素、および $\alpha$ $(2 \rightarrow 6)$ シアル酸転移酵素であり、これらは化学修飾された2-4糖 類似体を迅速に合成するのに適している。

\section{A. はじめに}

細胞上のオリゴ糖が各種の認識現象に深くかかわっている ことが明らかになるにつれ(1)、天然および非天然型のオリゴ糖 合成に関する興味が高まってきている。オリゴ糖は、バクテリ ア、ウイルス、毒素、およびホルモンが動物細胞に結合すると きの結合部位となる一方、細胞同士の接着においても重要な役 割を果たしている。また、細胞の正常あるいは異常な発生の過 程で、細胞表層上のオリゴ糖はその形を変化させる。したがっ て、競争的リガンドとして機能するオリゴ糖は、感染症(2)、炎 症(3-5)、あるいは癌(6、7)の治療薬として期待が持たれる。

オリゴ糖の化学合成は確立された技術である一方、時間が かかり特殊な技術を必要とする(8-10)。化学的手法と酵素的手 法を併用したオリゴ糖の合成(11-16)は、化学的手法のみによる 合成に代わるものとして関心を集めつつある。糖転移醉素のク ローニングが淮むにつれ(17-20)この手法はますます関心を集め るであろう。

哺乳類が持つオリゴ糖は、糖受容体の水酸基に糖又クレオ チドの単糖部分を転移させる糖転移醳素によって生合成されて いる(21)(図1)。

哺乳動物の代謝経路において見いだせれるヌクレオチド供 与体としては、UDP-D-グルコース(UDP-Glc)、UDP-N-アセチ ル-D-グルコサミン(UDP-GIcNAc)、UDP-D-ガラクトース(UDPGal)、UDP-N-アセチル-D-ガラクトサミン(UDP-GalNAc)、UDP- 


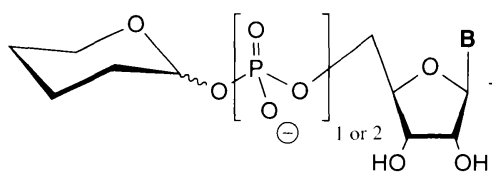

glycosyl donor

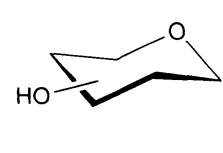

acceptor

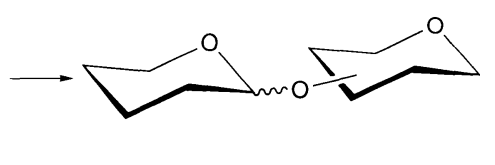

oligosaccharide

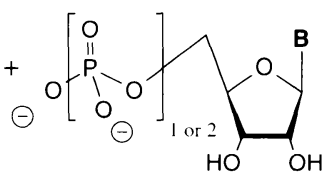

nucleotide

Fig. 1. A generalized glycosyltransferase reaction. All the sugar nucleotides are diphosphates in mammalian oligosaccharide biosynthesis except for CMP-sialic acid.

lose (UDP-Xyl), UDP-D-glucuronic acid (UDP-GlcA), GDPL-fucose (GDP-Fuc), GDP-D-mannose (GDP-Man), and CMPsialic acid. Glycosyltransferases have a high degree of specificity for the linkages that they form, catalyzing transfer from donor to acceptor regio- and stereospecifically. Well over one hundred different glycosyltransferases must exist to account for all known oligosaccharide structures.

It has been found that only a few of the hydroxyl groups, i.e., "key polar groups" $(22,23)$, in the acceptor substrate are usually required for recognition by these enzymes. This phenomenon has been observed in other carbohydrate-protein recognition systems including antibodies, lectins, glycosidases and oxidases (24-27). The approach to discovering the identity of such polar groups is to cause a perturbation at each of the $\mathrm{OH}$ groups on an oligosaccharide ligand, replacing them in turn with $\mathrm{H}$ (deoxy analogs), $\mathrm{OCH}_{3}, \mathrm{NH}_{2}$ or other groups. Such acceptor mapping has been performed for the bovine milk $\beta(1 \rightarrow 4)$-galactosyltransferase $(28,29)$, cloned $\alpha 1,3$ and $\alpha 1,4$ fucosyltransferases (30), $\alpha 2,3$ and $\alpha 2,6$ sialyltransferases that transfer to type I and type II acceptors (31), $\alpha 2,3$ sialyltransferases that transfer to T-disaccharides (32), $\mathrm{N}$-acetylglucosaminyltransferase $\mathrm{V}(33,34), N$-acetylgluco-saminyltransferase I (35), $N$-acetylglucosaminyltransferase II (36), core $2 \beta 1,6 \mathrm{~N}$-acetylglucosaminyltransferase (32), and the blood group A and B biosynthesizing enzymes $(37,38)$. Modifications are then frequently tolerated at other positions on the acceptors allowing the preparation of unnatural structures starting with acceptor analogs.

All of the natural sugar nucleotides are now available commercially. Many of them can also be enzymatically prepared using recycling systems to lower their cost when large scale synthesis is required. Provided that the enzyme is available, along with a suitable acceptor, the synthesis of the "natural" oligosaccharide sequences is therefore relatively straightforward since it is the task that the enzyme has evolved to perform. In this article, however, we concentrate on the application of glycosyltransferases for the synthesis of oligosaccharide analogs, i.e., unnatural oligosaccharides. The term "unnatural", in the present context, is used to indicate that a glycosyl-transferase will either transfer a sugar that is different from the one it transfers in nature, or that it will transfer the normal
D-キシロース(UDP-Xyl)、UDP-D-グルクロン酸(UDP-GlcA)、 GDP-L-フコース(GDP-Fuc)、GDP-D-マンノース(GDP-Man)、 CMP-シアル酸などがある。一般に糖転移酵素はその結合形成に 関して非常に高い特異性を持っており、供与体から受容体への 転移を位置および立体特異的に触媒する。既知のオリゴ糖の構 造を考慮すると、優に100を超える糖転移酵素が存在するはずで ある。

これらの酵素が受容体基質を認識するにあたっては、通常 たった2、3個の水酸基、すなわち “鍵極性基(key polar groups)” (22、23)、だけが必要であることが判っている。この現象は、抗 体、レクチン、糖加水分解醅素、糖酸化醅素などのタンパク質 と糖との結合においても見いだされている(24-27)。こういった 極性基を見つける際には、オリゴ糖リガンドのそれぞれの水酸 基を $\mathrm{H}$ (デオキシ類似体)、 $\mathrm{OCH}_{3} 、 \mathrm{NH}_{2}$ などの置換基に変換するこ とによりその形や性質を変えてしまう方法が良く使われる。こ うした検索法は、牛乳由来の $\beta(1 \rightarrow 4)$ ガラクトース転移酵素 $(28$ 、 29)、クローニングされた $\alpha(1 \rightarrow 3)$ および $\alpha(1 \rightarrow 4)$ フコース転移酵 素 $(30) 、 I$ 型糖鎖あるいはII 型糖鎖に作用する $\alpha(2 \rightarrow 3)$ および $\alpha$ $(2 \rightarrow 6)$ シアル酸転移酵素 $(31) 、 \mathrm{~T}$ 型二糖に作用する $\alpha(2 \rightarrow 3)$ シアル 酸転移酵素(32)、N-アセチルグルコサミン転移酵素 $\mathrm{V}(33,34) 、$ N-アセチルグルコサミン転移酵素 I(35)、N-アセチルグルコサミ ン転移酵素I I (36)、2型コアの $\beta(1 \rightarrow 6) \mathrm{N}$-アセチルグルコサミン転 移酵素(32)、Aおよび $\mathrm{B}$ 型血液型物質合成酵素(37、38)などにお いて適用されている。受容体の鍵極性基以外の置換基を化学修 飾してもたいていの場合は問題がなく、非天然型のオリゴ糖合 成に利用できる。

現在すべての天然型糖ヌクレオチドは購入できる。大量合 成の場合は、糖又クレオチドはリサイクリングシステムにより 酵素合成でき、コストを下げることが可能である。酵素は“天然 型”オリゴ糖鎖を作るために産まれてきたのだから、適当な受容 体と酵素が入手できればこれを合成するのは比較的容易なはず である。しかしこの総説ではオリゴ糖類似体、つまり非天然型 オリゴ糖の糖転移酵素を用いた合成に焦点を置く。ここで“非天 然”という言葉は、糖転移酵素が天然において転移する単糖と違 う糖を転移する場合、あるいは天然型の単糖を天然型と違う受 容体に転移する場合に用いる。ラクトアルブミンの存在下ラク 
sugar to an acceptor that is different from the natural acceptor. Except for $\beta(1 \rightarrow 4)$-galactosyltransferase, which synthesizes lactose in the presence of lactalbumin $(21,28,39)$, all mammalian glycosyltransferases act on glycoproteins and glycolipids so that all small molecule oligosaccharide acceptors may be viewed as unnatural. In the present review, however, we do not consider a change in aglycone as creating an unnatural acceptor which we define as having a chemically modified sugar residue. Also, since the objective of the review is to summarize the utility of glycosyltransferases in the preparative synthesis of structurally-defined oligosaccharide analogs, we focus on cases where enzymatic products have been isolated and their structures verified by methods such as NMR-spectroscopy and mass-spectrometry.

Only four systems have been extensively studied with respect to both donor and acceptor modifications. These are bovine $\beta(1 \rightarrow 4)$-galactosyltransferase, $N$-acetylglucosaminyltransferase-I, $\alpha 3 / 4$-fucosyltransferases and the family of sialyltransferases. These are discussed in turn below.

\section{B. $\beta(1 \rightarrow 4)$-Galactosyltransferase}

UDP-galactose: $N$-acetylglucosaminide $\beta(1 \rightarrow 4)$ galactosyltransferase (GalT, E. C. 2.4.1.22/38) is the most intensively studied of the glycosyltransferases because it has been commercially available for many years in unit quantities, where a unit is defined as the amount of enzyme catalyzing the conversion of $1 \mu \mathrm{mol}$ of substrate to product per min. The enzyme transfers Gal from UDP-Gal to OH-4 of $\beta$-linked GlcNAc (Fig. 2) to produce $N$-acetyllactosamine. In the presence of the modifier protein $\alpha$-lactalbumin, its kinetics and specificity is altered to more efficiently use free glucose as the acceptor for the synthesis of lactose in lactating mammary glands.

\section{B-1. Donor Specificity: UDP-Gal}

Figure 2 shows that GalT is capable of transferring a large number of modified sugars from UDP. It will transfer 2deoxy-Gal (40-43) at a rate similar to Gal (43) and galactosamine is also transferred (42). Even GalNAc, where $\mathrm{OH}-2$ has been replaced with a bulky NHAc residue, is transferred at $0.2 \%$ of the rate of Gal (44), however, the rate of transfer increases up to $55 \%$ of the natural UDP-Gal in the presence of $\alpha$ lactalbumin for free GlcNAc acceptor (45). This enzyme has frequently been used to synthesize the $\beta \mathrm{GalNAc}(1 \rightarrow 4) \mathrm{GlcNAc}$ sequence found on glycoprotein hormones $(46,47)$. 3-Deoxy (48), 4-deoxy (49), and 6-deoxy Gal $(50,51)$, as well as 6fluoro-Gal $(50,51)$, Ara (where the $\mathrm{CH}_{2} \mathrm{OH}$ group is replaced by $\mathrm{H})(49,52)$ and Glc $(45,49,53)$, are also transferred. UDPGlcNAc is not a substrate (45) and neither is UDP-Man (unpublished data). In only one example was a double substitution examined: $\mathrm{GlcNH}_{2}$ was transferred with a relative rate of $0.9 \%$ compared to that of Gal (45).

UDP-5'-thio-Gal, where the ring oxygen of Gal has
トースを合成する $\beta(1 \rightarrow 4)$ ガラクトース転移酵素 $(21 、 28 、 39)$ を除 けば、すべての動物細胞の糖転移酵素は糖タンパク質や糖脂質 を受容体として作用するので、すべての低分子オリゴ糖受容体 は非天然型とも見なせるかもしれない。しかしこの総説では、 化学修飾された糖残基を持つ受容体のみを非天然型と定義し、 それ以外のアグリコン部分の変化については非天然型と見なさ ないことにする。また、この総説では構造が明確なオリゴ糖類 似体を大量に合成寸る際の糖転移酵素の利用について述べるの で、生成物が単離されその構造がNMRやマススペクトルで確認 されたものについてだけとりあげる。

種々の化学修飾が供与体と受容体の両基質について行われ た糖転移酵素は、牛乳由来の $\beta(1 \rightarrow 4)$ ガラクトース転移酵素、Nアセチルグルコサミン転移酵素 I、 $\alpha(1 \rightarrow 3 / 4)$ フコース転移酵素、 シアル酸転移酵素群の4つしかない。これらを順にとりあげてい $<。$

B. $\beta(1 \rightarrow 4)$ ガラクトース転移酵素

UDP-ガラクトース: N-アセチルグルコサミニド $\beta(1 \rightarrow 4)$ ガラ クトース転移酵素( GalT、E. C. 2.4.1.22/38)はかなり古くから工 ニット単位で購入可能なため最もよく研究されている。(1工 ニットは1分間に $1 \mathrm{mmol}$ の基質を変換するのに要する酵素の量で 定義される)この酵素はUDP-Galから $\beta$ グリコシド結合を持つ GlcNAcのOH-4にGalを転移しN-アセチルラクトサミンを生産す る(図2)。エフェクタータンパクである $\alpha$-ラクトアルブミンが存 在すると反応速度や基質特異性が变化し、より容易にグルコー スを受容体として認識するようになる。これにより乳腺ではラ クトースが合成される。

\section{B-1.供与体特異性(UDP-Gal)}

図2は種々の修飾UDP-GalがGalTによって転移される様子 を示している。2-デオキシ-Gal(40-43)はGal(43)と同様の速度で 転移され、ガラクトサミンも基質となる(42)。OH-2が高高い NHAcで置換されたGalNAcですら Galの0.2\%の速度で転移され る(44)。しかし $\alpha$-ラクトアルブミンが存在すると反応速度が向 上し、GalNAcはGalの55\%の速度でGlcNAcに転移される(45)。 この酵素は糖タンパクホルモンに見られる $\beta$ GalNAc $(1 \rightarrow 4)$ GlcNAcを合成するのによく使われている(46、47)。3-デオキシ (48)、4-デオキシ(49)、6-デオキシ(50、51)、6-フルオロ-Gal(50、 $51)$ やアラビノース $\left(\mathrm{Gal}\right.$ の $\mathrm{CH}_{2} \mathrm{OH}$ が $\mathrm{H}$ に置換されたもの)(49、 52)、GIc(45、49、53)なども転移される。UDP-GIcNAc(45) と UDP-Man(未発表データ)は基質とならない。2䇢所の置換基が同 時に置換された例は1つだけあり、GIcNH 速度で転移される(45)。

Galの環酸素が硫黄原子で置換されたUDP-5'-チオ-Galはこ 

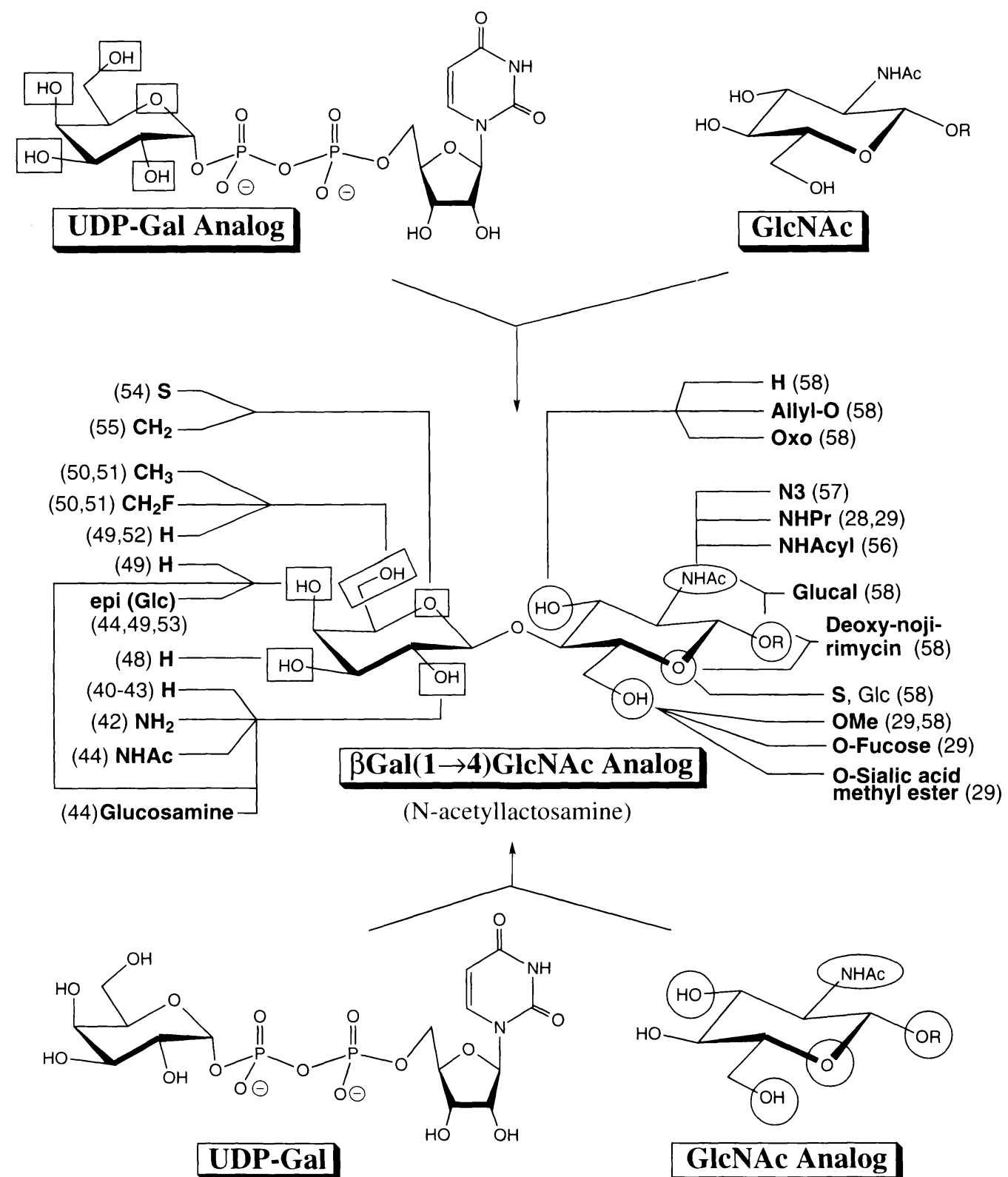

Fig. 2. Use of GalT in the synthesis of $N$-acetyllactosamine analogs. Groups on the Gal residue where modifications are tolerated by the enzyme are shown inside squares in both the donor and the product. Groups on the GlcNAc residue where modifications are tolerated by the enzyme are circled in both the acceptor and the product. The individual analogs synthesized are shown in the product only and the reference corresponding to each analog is given in brackets adjacent to the specific chemical modification that is tolerated inside the square or the circle. For example, the synthesis of the analog of $\mathrm{N}$-acetyllactosamine with a sulfur in the galactose ring was accomplished using a UDP-Gal analog with sulfur in the ring, and unmodified GlcNAc as acceptor, as reported in reference 54 .

been replaced with a sulfur atom, remains an active substrate for the enzyme which has been used to synthesize 5 '-thio- $N$ acetyllactosamine (54), an analog of $N$-acetyllactosamine which has increased resistance to galactosidases. The "carba" analog of UDP-Gal, where the ring oxygen is replaced by a methylene group, has also been synthesized but is not active as a donor (55).

\section{B-2. Acceptor Specificity: BGIcNAc}

As noted above, the enzyme can transfer also to Glc and
の酵素の活性基質であり、5'-チオ-N-アセチルラクトサミンの合 成に使われている(54)。このN-アセチルラクトサミン類似体は ガラクトシダーゼに対してより強い耐性を示す。Galの環酸素が メチレンで置換されたUDP-Galの“カルバ”類似体が合成されて いるが、供与体としては不活性である(55)。

\section{B-2.受容体特異性: $\beta$ GIcNAc}

先に触れたように、この酵素はグルコースを受容体とする 
therefore functions in the synthesis of lactose. The specificity of the enzyme for the acceptor is extremely relaxed as a very large number of modified GlcNAc and Glc analogs are active as acceptors (Fig. 2.). Basically, GalT tolerates substitutions everywhere on the sugar ring as long as $\mathrm{OH}-4$ remains available for glycosylation. The acetamido group can be replaced with a large number of amides (including alkylamido, benzamido etc.) (56), propionyl (28) and azido (57) resulting in even better acceptor properties. O-3 can be deoxygenated, $O$-methylated, $O$ allylated or oxidized to the ketone and still remain active as an acceptor though the rate of transfer is much slower (58). 6- $O$ Methylated $(29,58)$ or $\alpha$-L-fucosylated GlcNAc derivatives (29) remain fully active as acceptors. Addition of $\alpha$-linked sialic acid to OH-6 of GlcNAc abolishes activity, but this can be restored if the carboxylic acid is present as its methyl ester (29).

The exceptional tolerance of this enzyme for modifications to the GlcNAc (or Glc) moiety is clear and further exemplified by the fact that it will transfer to 5-thio-Glc, 1-deoxynojirimycin and glucal which has a flattened conformation with a double bond between $\mathrm{Cl}$ and $\mathrm{C} 2$ (58). When the artificial acceptor 3-acetamido-3-deoxy-Glc is used, an unusual $(1 \rightarrow 1)$ (trehalose type) of linkage was formed (59). This has also been reported for $\mathrm{N}$-acetylgentosamine and $\mathrm{N}$-acetyl 5-thiogentosamine as acceptor substrates $(60,61)$.

Other examples of note are the transfer of galactose to $\mathrm{N}$-acetylglucosamine or glucose acceptors bound to resins, including soluble polyacrylamide resins $(62,63)$, soluble light sensitive polymers $(64,65)$, silica based solid-supports (66) and polyethylene-polyacrylamide co-polymers for solid-phase glycopeptide synthesis (67).

\section{C. $N$-Acetylglucosaminyltransferase I}

UDP-GlcNAc: Mannoside $(\alpha 1 \rightarrow 3)-\mathrm{R} \quad \beta(1 \rightarrow 2)-N$ acetylglucosaminyltransferase I (GlcNAcT-I, E. C. 2.4.1.101) is not commercially available but a synthetically useful partially purified preparation is obtainable from animal tissues (68, $69)$. The enzyme has been cloned yielding a much cleaner and more useful preparation thus enhancing its application in ana$\log$ synthesis $(35,70-73)$. The enzyme requires, as a minimum substrate, a trisaccharide which in the natural glycoprotein substrates is the "tri-Man core": $\alpha \operatorname{Man}(1 \rightarrow 3)[\alpha \operatorname{Man}(1 \rightarrow 6)]$ $\beta$ Man-OR (Fig. 3) . The reducing end $\beta$ Man may be changed for $\beta \mathrm{Glc}$, resulting in a trisaccharide that is easier to synthesize (74) . Twelve oligosaccharide analogs have been synthesized using this enzyme.

\section{C-1. Donor Specificity: UDP-GIcNAc}

Each of the 3 mono-deoxygenated analogs of UDPGlcNAc (Fig. 3) was chemically synthesized and found to be active as a donor, producing the expected deoxy-tetrasaccharides $(48,68)$. The 4 -deoxy analog was the poorest sub-
こともでき、ラクトースの合成に関与している。非常に多くの 修飾GlcNAcおよびGlc類似体が受容体として活性であることか ら判るように、この酵素の受容体に対する特異性は非常にゆる い(図2)。グリコシル化が起こるOH-4が残されていれば、GalTは 原則として受容体のどの置換基が修飾されていても認識でき る。アセタミド基は多くのアミド(アルキルアミド、ベンザミド など)(56)と交換できるし、プロピオニルアミド基(28)やアジド 基(57)に置換すればよりよい受容体となる。GlcNAcのO-3は、 デオキシ化、O-メチル化、O-アリル化、あるいは酸化を行って ケトンにしても、反応速度はずっと遅いものの、受容体として なお活性である(58)。O-6がメチル化された(29、58)、あるいは $\alpha$-L-フコース化された(29)GlcNAc誘導体は受容体として通常通 りの活性を示す。GlcNAcのOH-6に $\alpha$-グリコシド結合でシアル 酸が結合したものでは活性が完全に失われる。しかし、そのカ ルボン酸をメチルエステルに置き換えると活性は回復する (29)。

この酵素がGlcNAcの(あるいはGlcの)修飾に対して寛容で あることは明らかであり、5-チオ-Glc、1-デオキシノジリマイシ ンや、C1とC2の間の二重結合のため平たくつぶれたコンホメー ションを持つグルカールが転移を受けることからもさらに支持 される(58)。合成受容体である3-アセ夕ミド-5-デオキシ-Glcを用 いると珍しい $(1 \rightarrow 1)$ 結合(トレハロース型)が形成される(59)。NアセチルゲントサミンやN-アセチル 5-チオーゲントサミンを受容 体としても同様の結果となる $(60 、 61)$ 。

他の興味梁い例として、N-アセチルグルコサミンやグル コースを可溶性ポリアクリルアミド樹脂(62、63)、可溶性光感受 性ポリマー(64、65)、シリカゲル固相支持体(66)、ポリエチレンポリアクリルアミド共重合体(67)などに固定化したものを糖ぺ プチドの固相合成のために受容体として用いる例がある。

\section{N-アセチルグルコサミン転移酵素 |}

UDP-GlcNAc: マンノシド( $\alpha 1 \rightarrow 3)-R \beta(1 \rightarrow 2)-N$-アセチルグ ルコサミン転移酵素 I (GlcNAcT-I、E. C. 2.4.1.101)は市販されて いない。しかし、酵素合成に使用可能な部分精製品は動物組織 から調製できる(68、69)。この酵素はクローニングされており、 より容易に精製度が高いものが入手できるのでオリゴ糖類似体 合成に活発に利用されている(35、70-73)。この酵素が生合成に おいて最小限必要とする受容体の構造は“tri-Manコア”、すなわ $ち \alpha \operatorname{Man}(1 \rightarrow 3)[\alpha \operatorname{Man}(1 \rightarrow 6)] \beta M a n O R て ゙ あ る($ 図3)。還元末端の $\beta M a n か ゙ \beta G l c に$ 変換された三糖も受容体であり、これは合成が比 較的容易である(74)。20例のオリゴ糖類似体がこの酵素を用い て合成されている。

\section{C-1. 供与体特異性 :UDP-GICNAC}

可能な3つのUDP-GlcNAcデオキシ類似体(図3)が化学合成 され、それぞれが供与体として活性であることが判り、予想さ れるデオキシ四糖が合成されている(48、68)。この中では4-デオ 


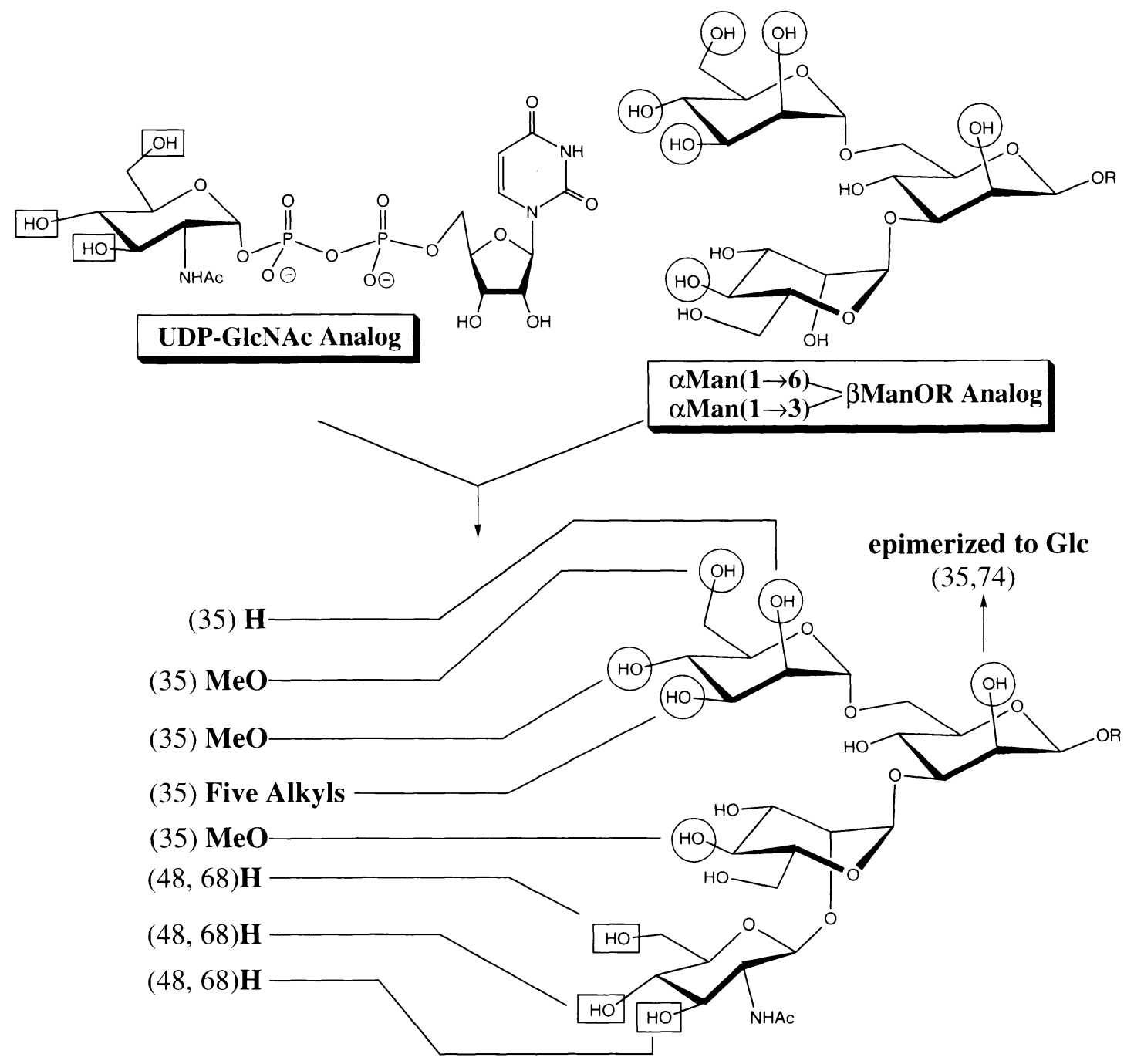
$\begin{array}{r}\alpha \operatorname{Man}(1 \rightarrow 6) \\ \beta \operatorname{GICNAc}(1 \rightarrow 2) \alpha \operatorname{Man}(1 \rightarrow 3)\end{array}>\beta \operatorname{ManOR}$ Analog

Fig. 3. Use of GIcNAcT-I in the synthesis of tetrasaccharide analogs. Modifications on the GlcNAc residue that are tolerated by the enzyme are shown inside squares and modifications on the trisaccharide acceptor that are tolerated by the enzyme are shown inside circles. The literature citation describing each modification is given in brackets.

strate.

\section{C-2. Acceptor Specificity: $\alpha \operatorname{Man}(1 \rightarrow 3)[\alpha \operatorname{Man}(1 \rightarrow 6)]$ $\beta$ Man or Glc-OR}

Recombinant GlcNAcT-I has proven especially useful in the synthesis of tetrasaccharide analogs which have been used to assess the specificity of the next GlcNAc-transferase (GlcNAcT-II) acting in the biosynthesis of complex Asn-linked oligosaccharides. GlcNAcT-I readily tolerates substitutions on the $\alpha \operatorname{Man}(1 \rightarrow 6)$ residue, either deoxygenation or $O$-alkylation. OH-3 of this residue could be modified by 5 different alkyl groups, including a 4,4-azo-pentyl photoaffinity label (35). $\mathrm{OH}-4$ of the $\alpha \mathrm{Man}(1 \rightarrow 3)$ residue, the mannose residue to which transfer occurs, could be $O$-methylated and still remain a
キシ類似体の活性が最も低い。

C-2. 受容体特異性: $\alpha \operatorname{Man}(1 \rightarrow 3)[\alpha \operatorname{Man}(1 \rightarrow 6)] \beta \operatorname{Man}$ たは GlcOR

クローン化されたGlcNAcT-Iは、Asn型糖鎖の生合成におい て次に作用するGlcNAc糖転移酵素(GlcNAcT-II)の受容体特異性 を調べるための四糖類似体の合成に適している。GlcNAcT-Iは $\alpha \operatorname{Man}(1 \rightarrow 6)$ 残基上のデオキシ化、O-アルキル化などの置換に対 しては影響を受けない。この残基のOH-3は4,4-アゾペ゚チル光 親和性ラベルを含む5つの異なるアルキル基によって修飾が可能 である(35)。転移を受ける $\alpha \operatorname{Man}(1 \rightarrow 3)$ 残基のOH-4はメチル化さ 
good substrate (35).

\section{D. $\alpha(1 \rightarrow 3 / 4)$-Fucosyltransferases:}

GDP-Fuc: $\beta \mathrm{Gal}(1 \rightarrow 4 / 3) \mathrm{GlcNAc}(\alpha 1 \rightarrow 3 / 4$ to GlcNAc) fucosyltransferase $(\alpha(1 \rightarrow 3 / 4)$-FucT, E. C. 2.4.1.65) is one of an expanding family of fucosyltransferases designated FucTIII, IV, V, VI and VII that transfer to the secondary alcohol of the GlcNAc residue in $\beta \mathrm{Gal}(1 \rightarrow 3) \mathrm{GlcNAc}$ and/or $\beta \operatorname{Gal}(1 \rightarrow 4)$ GlcNAc sequences $(21,75,76)$ (Fig. 4). The products are the blood-group related antigenic determinants termed Lewis-a $\left(\operatorname{Le}^{\mathrm{u}}\right)$ and Lewis- $\mathrm{x}\left(\mathrm{Le}^{\mathrm{x}}\right)$. The enzymes differ in their ability to utilize both sequences, and in their tolerance for sialic acid substitution at $\mathrm{O}-3$ or fucose substitution at $\mathrm{O}-2$ of the Gal residue in these acceptors. All five FucT's have been cloned, but they are not yet commercially available. The most convenient source for isolation of a preparatively useful enzyme is human milk (77). The milk enzyme preparation contains two FucT's, one acting on both Gal-GlcNAc sequences and the other only to $N$-acetyllactosamine, the $\beta(1 \rightarrow 4)$ linked disaccharide. Since in preparative oligosaccharide and analog synthesis the structure of the acceptor is controlled, use of such a mixture of enzymes does not present any difficulty for preparative synthesis.

\section{D-1. Donor Specificity: GDP-Fuc}

The major stumbling block to the use of these enzymes was until recently the lack of a simple method for the synthesis of GDP-Fuc which only became commercially available 3 years ago. Several methods are now in use (14) and the methods are sufficiently mild to allow the synthesis of analogs also. Eight different GDP-Fuc analogs have been shown to transfer (Fig. 4). The simplest analogs are modified at C-6 by either removal of the methyl group (to give GDP-D-Ara) (78) or by addition of a hydroxyl group (to give GDP-L-Gal) (79) which can be further $O$-propylated (80). A doubly-modified derivative where $\mathrm{OH}-3$ has been deoxygenated and $\mathrm{C}-6$ has been hydroxylated (to give 3-deoxy-L-Gal) was also shown to be preparatively useful (79), all using the $\beta \mathrm{Gal}(1 \rightarrow 3) \beta \mathrm{GlcNAc-OR}$ as the acceptor for the human milk enzyme.

The fact that the Fuc-methyl group could be extended by a much larger $O$-propyl group suggested that this part of the fucose residue was exposed to water, so GDP-Fuc derivatives with very much larger substitutions were prepared and indeed found to be active. Substitution of C- 6 of the Fuc residue in GDP-Fuc by an amino-group linked to a blood group B trisaccharide (Fig. 4) gave a compound that was used by the FucT to label red blood cells (80). Essentially any group can be attached at this position as was demonstrated by the transfer to $\mathrm{N}$ acetyllactosamine of a biotinylated fucose residue and a fucose residue carrying the blood group A trisaccharide attached through a squarate linker (81) (Fig. 4).
れてもまだ良好な基質である(35)。

\section{D. $\alpha(1 \rightarrow 3 / 4)$ フコース転移酵素}

GDP-Fuc: $\beta \operatorname{Gal}(1 \rightarrow 4 / 3) \operatorname{GlcNAc}(\alpha 1 \rightarrow 3 / 4$ to GlcNAc) フコー 又転移酵素 $(\alpha(1 \rightarrow 3 / 4)$-FucT、 E. C. 2.4.1.65)は $\beta \mathrm{Gal}(1 \rightarrow 3) \mathrm{GlcNAc}$ あるいは $\beta \mathrm{Gal}(1 \rightarrow 4) \mathrm{GlcNAc}$ GlcNAc残基の二級水酸基に転移を 起こすFucT-III、IV、V、VI、VIIなどと表記される一群のフ コース転移酵素の一つである(21、75、76)(図4)。ルイス-a(Lei) 抒 よびルイス-x $\left(\mathrm{Le}^{\mathrm{x}}\right)$ と呼ばれる血液型関連抗原決定基が生成物と なる。2つの受容体に対する特異性、これら受容体のGal残基の O-3におけるシアル酸の置換やO-2におけるフコースの置換に対 する許容度などがこれらの酵素の違いとなってあらわれる。5つ のFucTはすべてクローニングされているが、市販はされていな い。合成用の酵素として一番簡単に単離出来るのは人乳のもの である(77)。こうして単離された酵素は2つのFucTを含んでお

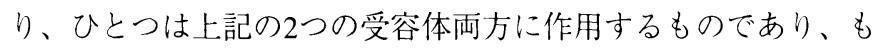
うひとつは $\beta(1 \rightarrow 4)$ 結合を持つ二糖であるN-アセチルラクトサミ ンだけに作用するものである。オリゴ糖や類似体の合成におい ては受容体の構造はたいていの場合単一のものを使うので、こ のような酵素の混合物を使っても何の支障もきたさない。

\section{D-1. 供与体特異性: GDP-Fuc}

GDP-Fucは3年前に市販されるようになったが、最近まで 簡単な合成法がなかったことがこれらの酵素を使用する上での 一番の障害であった。最近ではいくつかの合成法が見いだされ ており(14)、これらは類似体の合成を行うのにも充分マイルド な方法である。8つの異なるGDP-Fuc類似体が転移を受けること が判っている(図4)。一番簡単な類似体としては、C-6が除去さ れたもの(GDP-D-Ara)(78)やC-6に水酸基が付加されたもの(GDPL-Gal)(79)、さらにその水酸基がプロピル化されたもの(80)など がある。OH-3がデオキシ化されC-6に水酸基が付加され、二重 に修飾されたもの(3-デオキシ-L-Gal)も転移することが判ってい る(79)。受容体には $3 \mathrm{Gal}(1 \rightarrow 4) \beta \mathrm{GlcNAc}-\mathrm{OR}$ が用いられ、酵素は 天然から単離されたものが用いられている。

フコースのメチル基に嵩高いプロピル基がついても活性が あることから、この部分は酵素に認識されず水にむき出しに なっていることが示唆される。そこでGDP-Fucに非常に大きな 置換基がついたものを合成したところ、実際にこれが酵素の基 質となることが示されている。血液型関連B型三糖(図4)が結合 したアミノ基によりFucのC-6が置換されたGDP-Fucは、FucTに より赤血球細胞をラベルするのに用いられている(80)。ビオチ ンがついたフコース残基やA血液型三糖がスクアレートを介し て結合したフコース残基がN-アセチルラクトサミンに転移する 例で示されるように、基本的にこの位置にはどんな置換基でも 結合することが可能である(81)(図4)。 


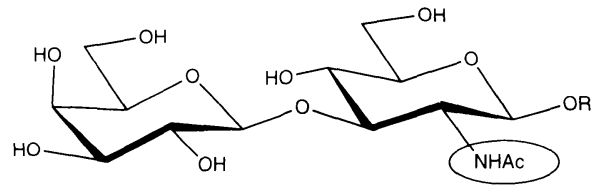

$\beta$ Gal $(1 \rightarrow 3)$ GlcNAc

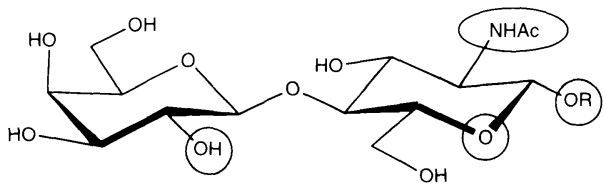

$\beta$ Gal $(1 \rightarrow 4)$ GIcNAc

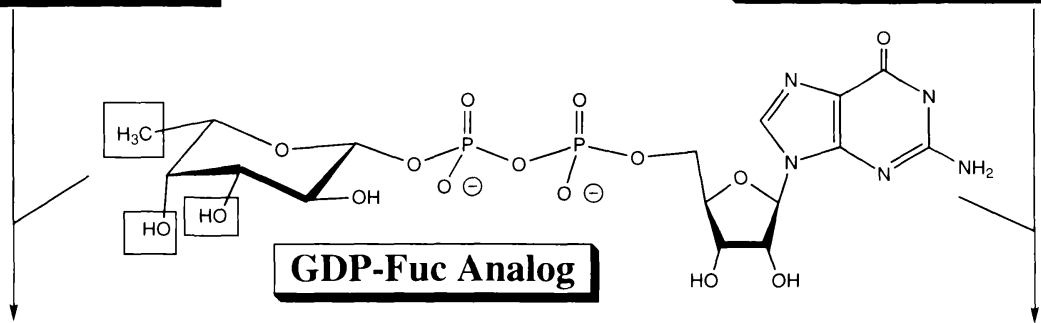

(78) $\mathrm{H}$

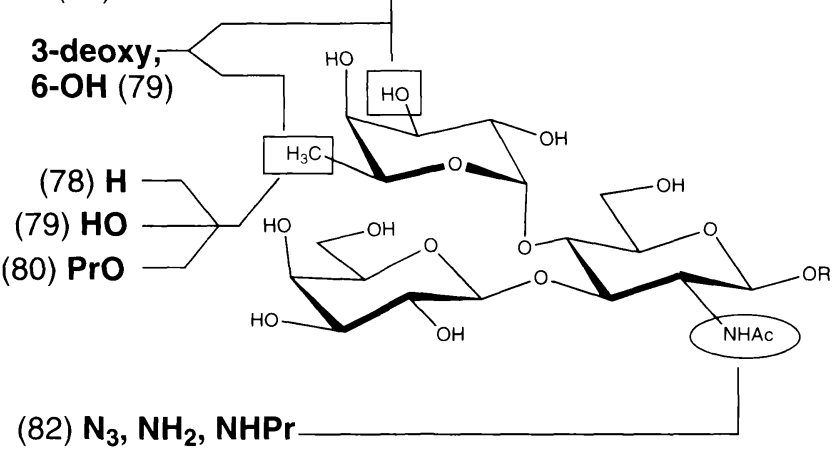

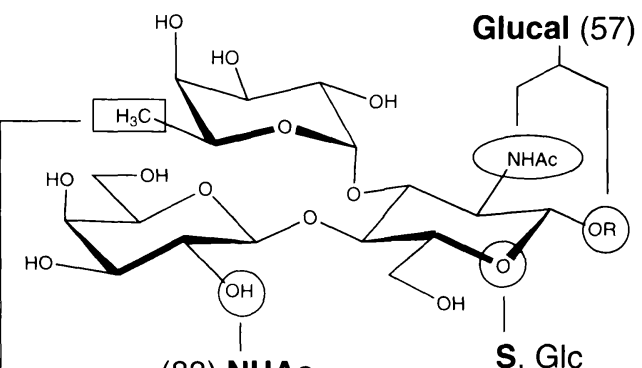

(83) NHAC

S, Glo

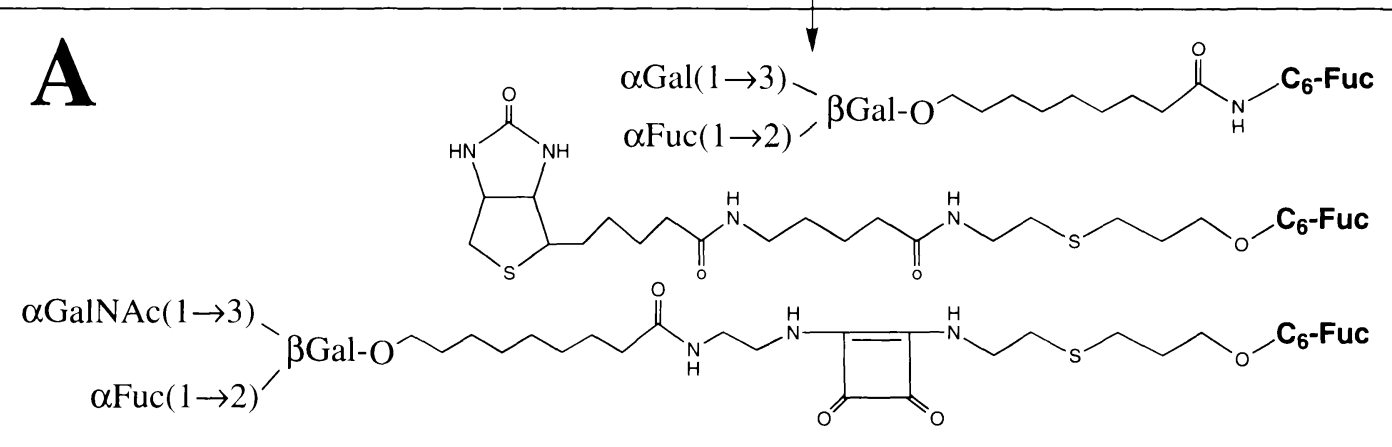

B

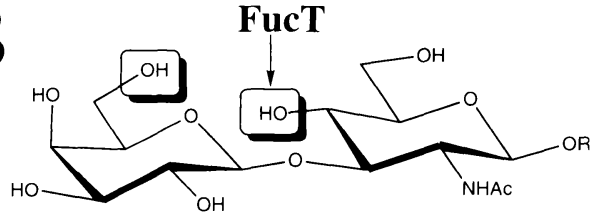

$\beta$ Gal $(1 \rightarrow 3)$ GIcNAc

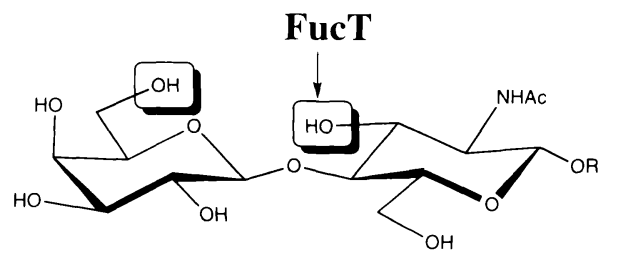

$\beta$ Gal $(1 \rightarrow 4)$ GIcNAc

$\square=$ key polar group

Fig. 4. Use of FucT in the synthesis of trisaccharide analogs. Modifications on the Fuc residue that are tolerated by the enzyme are shown inside squares and modifications on the disaccharide acceptors that are tolerated by the enzyme are shown inside circles. The literature citation describing each modification is given in brackets. Inset A shows the variety of large substituents that have been attached at C-6 of the Fuc residue in GDP-Fuc and transferred to $N$-acetyllactosamine. Inset B summarizes the results of the systematic study of acceptor specificity by de Vries et al. (30) which found that only OH-6 of the Gal residue and the $\mathrm{OH}$ group to which the enzyme transfers are essential for acceptor recognition. These "key polar groups" are highlighted. 


\section{D-2. Acceptor Specificity: $\beta$ Gal $(1 \rightarrow 3)$ GlcNAc and/or $\beta \mathrm{Gal}(1 \rightarrow 4)$ GlcNAc}

Several analogs of $\beta \mathrm{Gal}(1 \rightarrow 4) \mathrm{GlcNAc}$ have been preparatively fucosylated. Most notably, the FucT accepts replacement of the GlcNAc residue in this disaccharide by Glc, by 5 thio-Glc (with sulfur in the ring) and by glucal (57). In addition, the acetamido group can be replaced by a variety of groups including other bulky $N$-acyl groups (82) as well as the azido group (82). Transfer also occurs to other "natural" sequences which may be viewed as analogs; namely $\beta$ GalNAc $(1 \rightarrow 4)$ BGlcNAc (83).

The acceptor specificity of recombinant FucT-III, IV and $\mathrm{V}$, and some of their truncated forms, has been mapped out in detail using chemically synthesized analogs of both $\beta G a l(1 \rightarrow 3) \beta G l c N A c$ and $\beta$ Gal $(1 \rightarrow 4) \beta G l c N A c$ glycosides (30). Though preparative reactions were not carried out in that recent study, the summary is included in Fig. 4 to assist potential users of the FucT's in analog synthesis. Basically, substitutions of varying kinds, mostly deoxygenations, are tolerated at all position except at $\mathrm{OH}-6$ of $\mathrm{Gal}$ and the $\mathrm{OH}$-group to which the FucT's transfer, i.e. either OH-3 or OH-4 of the GlcNAc residues. As noted earlier, sialic acid substituted at O-3 of Gal, or fucose substituted at O-2 of Gal, are tolerated by some of the FucT's.

\section{E. $\alpha(\mathbf{2} \rightarrow \mathbf{3})$ and $\alpha(\mathbf{2} \rightarrow \mathbf{6})$-Sialyltransferases}

There are four enzymes in this group, all of which use CMP-sialic acid (the only monophosphate donor in mammalian cells) as the donor and all transfer to either OH-3 or 6 of terminal Gal residues or OH- 6 of GalNAc residues. They are most conveniently distinguished by their ability to utilize either $\beta \mathrm{Gal}(1 \rightarrow 3) \mathrm{GlcNAc}$ and/or $\beta \mathrm{Gal}(1 \rightarrow 4) \mathrm{GlcNAc}(N$ acetyllactosamine) sequences commonly found on $N$-linked oligosaccharides as opposed to either $\mathrm{OH}-3$ of the terminal Gal residue in $\beta \mathrm{Gal}(1 \rightarrow 3) \alpha \mathrm{GalNAc}$ or OH- 6 of $\alpha$-GalNAc residues found in $O$-linked glycopeptides. The enzymes have E.C. numbers 2.4.99.1, 2.4.99.3, 2.4.99.4 and 2.4.99.6. Their acceptor specificities are shown in Fig.5. The 2,3-sialyltransferase acting on $O$-linked structures (E.C. 2.4.99.1) and the 2,6sialyltransferase acting on $\mathrm{N}$-acetyllactosamine (E.C. 2.4.99.4) are commercially available in milliunit quantity.

\section{E-1. Donor Specificities: CMP-Sialic Acid}

The breakthrough in the study of the donor-specificity of these enzymes came with the finding that CMP-sialic acid synthetase could accept many sialic acid analogs as substrates thereby providing convenient access to the necessary CMPsialic acid analogs $(84,85)$. With the analogs then accessible, substrate specificities could be evaluated. Most of the donorspecificity studies regrettably determined only kinetic parameters for the transfer to glycoprotein substrates and the products
D-2. 受容体特異性: $\beta$ Gal $(1 \rightarrow 3)$ GlcNAcあるいは $\beta$ Gal $(1 \rightarrow 4)$ GICNAc

いくつかの $\beta \mathrm{Gal}(1 \rightarrow 4) \mathrm{GlcNAc}$ 類似体についてフコース転移 を受けたものが合成されている。この二糖のGlcNAc残基を Glc、5-チオ-Glc(環硫黄類似体)やグルカールに置き換えても活 性があるのは注目に值する(57)。さらに、アセ夕ミド基を高高 いN-アシル基やアジド基などに置き換えることも可能である (82)。類似体とも見なせる “天然”一糖すなわち $\beta$ GalNAc $(1 \rightarrow 4)$ BGlcNAcでも転移が起こる(83)。

クローン化されたFucT-III、IV、Vやそれらの活性断片の受 容体基質特異性は化学合成された $\beta \mathrm{Gal}(1 \rightarrow 3) \mathrm{GlcNAc} や \beta G a l$ $(1 \rightarrow 4) \mathrm{GlcNAc} の$ 類似体を用いて調べられている $(30)$ 。この最近 の研究ではプレパラティブな合成は行われていないが、将来 FucTを類似体合成に用いる方のために図 4にまとめを描いてお いた。基本的には、GalのOH-6やGlcNAcのOH-3あるいはOH-4 のように転移を受ける水酸基以外はデオキシ化などの置換に対 して許容である。前記したように、GalのO-3がシアル酸で置換 されていたり、GalのO-2がフコースで置換されていてもいくつ かのFucTについては問題がない。

\section{E. $\alpha(2 \rightarrow 3)$ および $\alpha(2 \rightarrow 6)$ シアル酸転移酵素}

これまでに4つのシアル酸転移酵素が用いられており、こ れらは全てCMP-シアル酸(動物細胞で唯一のモノリン酸供与体) を供与体として末端のGal残基のOH-3か6あるいはGalNAc残基 のOH-6に転移する。これらは、N-結合オリゴ糖によく見られる $\beta \operatorname{Gal}(1 \rightarrow 3) \mathrm{GlcNAc}$ $\beta \mathrm{Gal}(1 \rightarrow 4) \operatorname{GlcNAc}(N$-アセチルラクトサミ ン)を認識するのか、O-結合糖ぺプチドに見られる $\beta \mathrm{Gal}(1 \rightarrow 3)$ GalNAcの末端Gal残基のOH-3やGalNAc残基のOH-6を認識する のかにより大まかに分類できる。これらの酵素のE.C.ナンバー は2.4.99.1、2.4.99.3、2.4.99.4と2.4.99.6である。受容体特異性は 図5に示してある。O-結合オリゴ糖に作用する2、3-シアル酸転移 酵素(E.C. 2.4.99.1) とN-アセチルラクトサミンに作用する2、6-シ アル酸転移酵素(E.C. 2.4.99.4)はミリユニット単位で市販されて いる。

\section{E-1. 供与体特異性: CMP-シアル酸}

供与体特異性の研究は、CMP-シアル酸シンターゼが多く のシアル酸類似体を受け入れることが発見され、結果として CMP-シアル酸類似体をより容易に合成出来るようになったこと がブレークスルーとなって始まった $(84 、 85)$ 。類似体が入手でき れば、基質特異性を評価できるということである。残念なが ら、多くの供与体特異性の研究は糖夕ンパク受容体への転移の 速度パラメーターのみを求めるものであり、生成物の同定は行 

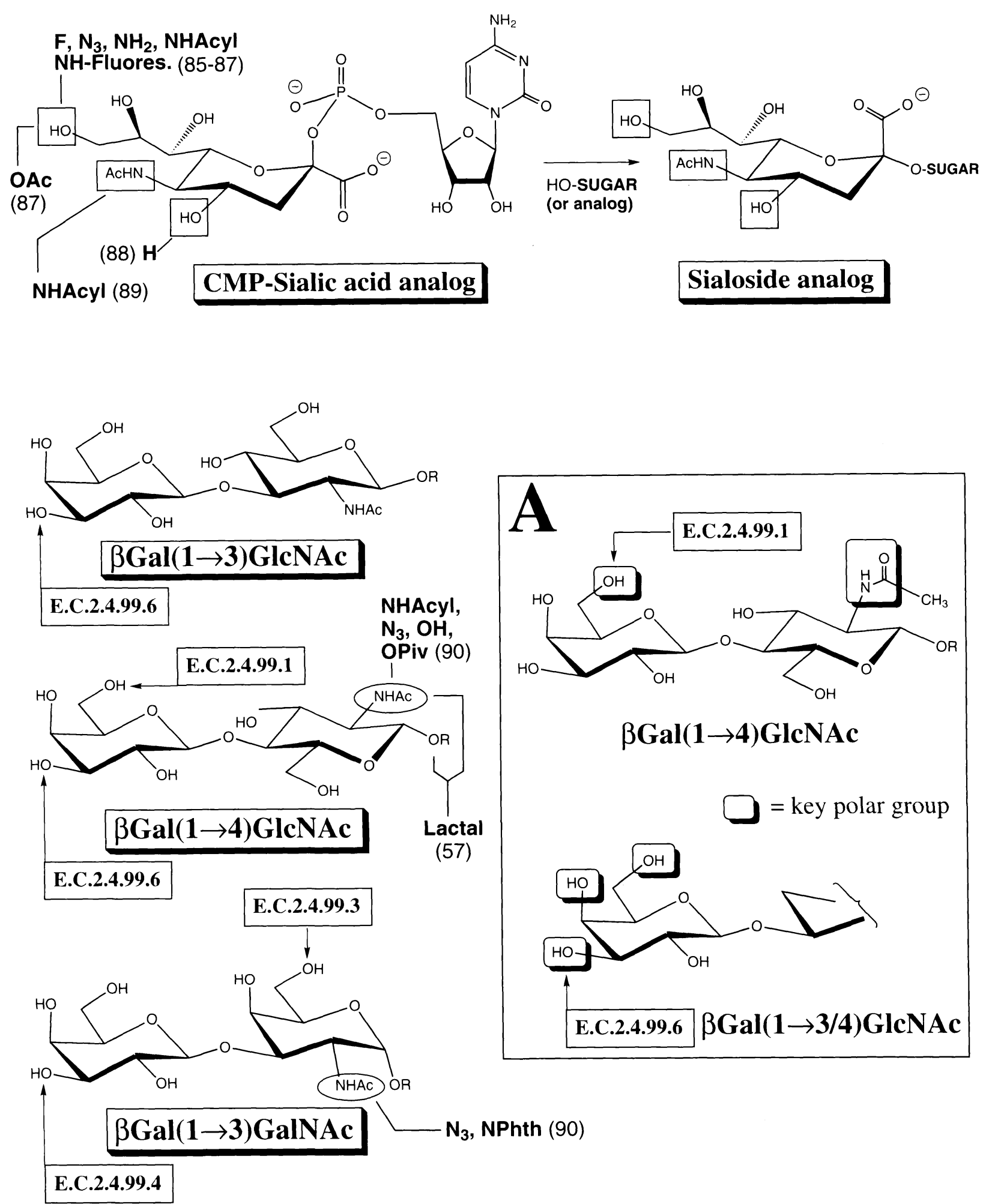

Fig. 5. Use of a family of sialyltransferases in the synthesis of oligosaccharide analogs. The acceptor specificity of each of the enzymes, along with its E.C. number, are presented. Modifications on the sialic acid residue that are tolerated by the enzymes are shown inside squares while modifications on the disaccharide acceptors are shown inside circles. The literature citation describing each modification is given in brackets. Inset A summarizes the results of the systematic study of acceptor specificity by Wlasichuk et al. (31) and indicates that only OH-6 (the OH-group to which the enzyme transfers) and an amide grouping are "key polar groups" for 2,6sialyltransferase while the 2,3-sialyltransferase requires an intact 3,4,6-triol system on the galactose unit. 
were not structurally characterized. Nevertheless, important information was gained about the tolerance of these enzymes for derivatives of CMP-sialic acid, and therefore on their potential use in the synthesis of analogs of sialylated oligosaccharides.

While the members of this group of enzymes certainly differ qualitatively in their tolerance for transferring modified sialic acid residues, they do share the same basic donor-recognition pattern (Fig. 5). Numerous substitutions were tolerated at $\mathrm{C}-9$, including the 9-fluoro and 9-azido derivatives and a large number of $\mathrm{N}$-acylated analogs like $\mathrm{N}$-benzamido and 9 hexanoylamido $(85,86)$. Even a $9-N$-fluoresceinyl labeled CMP-sialic acid derivative was a substrate (87). The 9-amino precursor itself was either a very poor or inactive donor. Similarly, 9-O-acetyl sialic acid could be transferred, though poorly. CMP- $N$-glycolyl-neuraminic acid was also a good donor (84). 4-Deoxy-sialic acid could also be transferred from the sugar nucleotide by the 2,6-sialyltransferase acting on $\mathrm{N}$-acetyllactosamine (88). Various $N$-acyl groups are tolerated by some of these enzymes (89).

\section{E-2. Acceptor Specificities}

The natural sequences acted on by the sialyltransferases are shown in Fig. 5 and were discussed above. Preparative synthesis using the sialyltransferases have targeted mostly the sialyl-Le ${ }^{x}$ and related tetrasaccharide analogs as potential antiinflammatory agents. They have been used in the preparation of both natural and modified structures (90). Numerous substitutions of the $\mathrm{N}$-acetyl group in $\mathrm{N}$-acetyllactosamine are tolerated by the 2,3 sialyltransferase which also accepts lactose and 2-O-pivaloyl lactose as acceptors (90). The same situation is found for the 2,3-sialyltransferase acting on $O$-linked disaccharides where an azido group and an $N$-phthalimido group are tolerated by the enzyme. The 2,3-sialyltransferase also acts on lactal further enhancing the utility of the enzyme in the synthesis of analogs (57).

A thorough study on the ability of chemically-modified analogs to act as acceptors has been performed only for the $\alpha(2,3)$ and $\alpha(2,6)$ specific enzymes which act on $N$-linked structures (E.C. 2.4.99.1 and 6) and is summarized in Fig. 5 (31).

\section{F. Conclusions}

In all of the cases above, the glycosyltransferases were found to be remarkably flexible in their recognition of both the donor and acceptor substrates. While the rates of transfer are sometimes only near $1 \%$ (or even less) of that of the natural reaction, such rates are nevertheless sufficient for the production of milligram, or larger, quantities of the product oligosaccharide analogs. In each case, however, there were some substitutions that the enzymes simply would not tolerate, most notably the deletion of one of a small number of key-polar groups.
われていない。しかしながら、これらの酵素に対するCMP-シア ル酸誘導体の許容度に関する情報が得られており、シアリル化 されなオリゴ糖類似体を合成する際に有用な情報となるであろ j。

これらの酵素のCMP-シアル酸類似体に対する基質特異性 はそれぞれ若干違うが、基本的には同様の認識パターンを示す (図5)。9-フルオロ、9-アジド誘導体やN-ベンズアミド、9-ヘキ サノイルアミドなどの多くのN-アシル類似体のC-9への置換は許 容である(85、86)。9位をフルオレセインアミドでラベルした

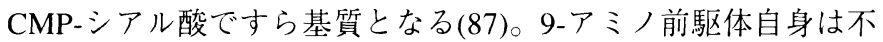
活性あるいは活性の弱い供与体である。CMP-N-グリコリル-ノ イラミン酸は良い供与体基質となる $(84)$ 。4-デオキシ-シアル酸 は2、6-シアル酸転移酵素により相当する糖ヌクレオチドから $N$ -

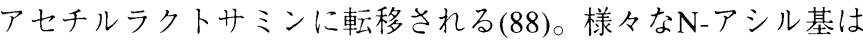
この酵素に対して許容である(89)。

\section{E-2. 受容体特異性}

上述したシアル酸転移酵素により認識される天然型糖鎖は 困5に示してある。シアル酸転移酵素を用いた合成では、主に抗 炎症薬として期待されるシアリルLe トとしている。これらの酵素は天然型と類似体の両方の合成に 用いられている $(90)$ 。2、3 シアル酸転移酵素ではN-アセチルラク トサミンのN-アセチル基の置換に対して許容であり、2-O-ピバ ロイルラクトースも受容体となる $(90)$ 。同様のことが $\mathrm{O}$-結合二 糖に作用する $2 、 3$ シアル酸転移酵素にも見いだされており、ア ジド基やN-フタルイミド基に置換されたものでも転移を受け る。2、3 シアル酸転移酵素がラクタールにも作用する事はこの 酵素が類似体合成に有用であることを示している(57)。

化学修飾された受容体に関する研究は、N-結合糖鎖に作用 する $\alpha(2 \rightarrow 3)$ 拈よび $\alpha(2 \rightarrow 6)$ 特異的酵素(E.C. 2.4.99.1 と6)について のみ行われており、図5にまとめてある(31)。

\section{F. 結 論}

糖転移酵素は、上記したすべての場合において供与体、受 容体の両方の認識について非常に柔軟性がある。転移速度が天 然の基質に比べて $1 \%$ 以下しかない場合もあるが、この程度なら ミリグラムスケールのオリゴ糖類似体の合成には十分である。 しかし、酵素が受け入れない基質の修飾がそれぞれの場合につ いて存在し、鍵極性基をひとつでも除去した場合には全く認識 
As more glycosyltransferases become available, along with better methods for sugar nucleotide synthesis, we expect the same situation to hold, i.e. these enzymes will be very useful in the synthesis of a large number, but not all desired oligosaccharide analogs. Glycosyltransferases may therefore be most effectively thought of as synthetic adjuncts in the synthesis of oligosaccharide analogs.

\section{G. Acknowledgments}

This review was prepared while on sabbatical leave at the RIKEN Institute. The authors acknowledge the support of Professor Tomoya Ogawa for making this sabbatical leave possible. Funding from the Japan Society for the Promotion of Science and the RIKEN Institute is gratefully acknowledged.

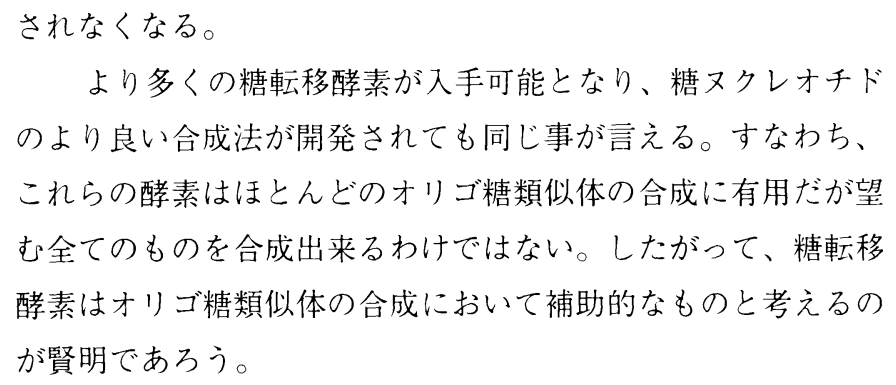

東京工業大学·生命理工 学部 ·生命理学

湯浅 英哉 訳

\section{References}

1. Varki, A. (1993) Glycobiology 3, 97-130

2. Karlsson, K.-A. (1995) Curr. Opin. Struct. Biol., in press

3. Phillips, M.L., Nudelman, E., Gaeta, F.C.A., Perez, M., Singhal, A.K., Hakomori, S., and Paulson, J.C. (1990) Science 250, $1130-1132$

4. Walz, G., Aruffo, A., Kolanus, W., Bevilacqua, M., and Seed, B. Science 250, 1132-1135

5. Lowe, J.B. (1994) in Molecular Glycobiology (Fukuda, M., and Hindsgaul, O., eds.) pp. 163-205, Oxford University Press

6. Hakomori, S. (1989) Adv. Cancer Res. 52, 257-331

7. Dennis, J.W. (1988) Cancer Surveys 7, 753-794

8. Paulsen, H. (1990) Angew. Chem. Int. Ed. Engl. 29, 823-839

9. Sinay, P. (1991) Pure Appl. Chem. 63, 519-528

10. Kanie, O., and Hindsgaul, O. (1992) Curr. Opin. Struct. Biol. 2, 674-681

11. Toone, E.J., Simon, E.S., Bednarski, M.D., and Whitesides, G.M. (1989) Tetrahedron 45, 5365-5422

12. David, S., Auge, C., and Gautheron, C. (1991) Adv. Carbohydr. Chem. Biochem. 49, 175-237

13. Drueckhammer, D.G., Hennen, W.J., Pederson, R.L., Barbas, C.F., Gautheron, C.M., Krach, T., and Wong, C.-H. (1991) Synthesis, 499525

14. Ichikawa, Y., Look, G.C., and Wong, C.-H. (1992) Anal. Biochem. 202, 215-238

15. Wong, C.-H., Halcomb, R.L., Ichikawa, Y., and Kajimoto, T. (1995) Angew. Chem. Int. Ed. Engl. 34, $521-546$

16. Crawley, S.C., and Palcic, M.M. (1995) in Modern Methods in Carbohydrate Synthesis (Khan, S. H., and O'Neill, R. A., eds.) pp. 492517, Harwood Academic Publishers

17. Paulson, J.C., and Colley, K.J. (1989) J. Biol. Chem. 264, 17615-17618

18. Kleene, R., and Berger, E.G. (1993) Biochim. Biophys. Acta 1154, 283-325

19. Lowe, J.B. (1991) Seminars Cell Biol. 2, 289-307

20. Schachter, H. (1994) in Molecular Glycobiology (Fukuda, M., and Hindsgaul, O., eds.) pp. 88-162, Oxford University Press

21. Beyer, T.A., Sadler, J.E., Rearick, J.I., Paulson, J.C., and Hill, R.L. (1982) Adv. Enzymol. 52, 23-175

22. Lemieux, R.U. (1989) Chem. Soc. Rev. 18, 347-374

23. Du, M.-H., Spohr, U., and Lemieux, R.U. (1994) Glycononj. J. 11, 443-461

24. Bundle, D.R., and Young, M.N. (1992) Curr. Opin. Struct. Biol. 2, 666-673

25. Glaudemans, C.P.J. (1991) Chem. Soc. Rev. 91, 25-33

26. Sierks, M.R., Bock, K., Refn, S., and Svensson, B. (1992) Biochemistry 31, 8972-8977

27. Striker, R.T., Nilsson, U., Stonecipher, A., Magnusson, G., and Hultgren, S.J. (1995) Mol. Microbiol. 16, $1021-1029$

28. Berliner, L.J., Davies, M.E., Ebner, K.E., Beyer, T.A., and Bell, J.E. (1984) Mol. Cell. Biochem. 62, 37-42

29. Palcic, M.M., Srivastava, O.P., and Hindsgaul, O. (1987) Carbohydr. Res. 159, 315-324

30. deVries, T., Srnka, C.A., Palcic, M.M., Sweidler, S.J., van den Eijnden, D.H., and Macher, B.A. (1995) J. Biol. Chem. 270, 87128722

31. Wlasichuk, K.B., Kashem, M.A., Nidra, P.V., Bird, P., Jiang, C., and Venot, A.P. (1993) J. Biol. Chem. 268, 13971-13977

32. Kuhns, W., Rutz, V., Paulsen, H., Matta, K.L., Baker, M.A., Barner, M., Granovsky, M., and Brockhausen, I. (1993) Glycoconj. J. 10, 381394

33. Kanie, O., Crawley, S.C., Palcic, M.M., and Hindsgaul, O. (1994) Bioorg. Med. Chem. 2, 1231-1241

34. Khan, S.H., Duus, J.O., Crawley, S.C., Palcic, M.M., and Hindsgaul, O. (1994) Tetrahedron: Asymmetry 5, 2415-2435

35. Reck, F. Springer, M., Paulsen, H., Brockhausen, I., Sarkar, M., and Schachter, H. (1995) Carbohydr. Res. 259, $93-101$

36. Reck, F., Meinjohanns, E., Springer, M., Wilkens, R., van Dorst, J.A.L.M., Paulsen, H., Moller, G., Brockhausen, I., and Schachter, H. (1994) Glycoconj. J. 11, 210-216

37. Lowary, T.L., and Hindsgaul, O. (1993) Carbohydr. Res. 249, 163-195

38. Lowary, T.L., and Hindsgaul, O. (1994) Carbohydr. Res. 251, 33-67

39. Hill., R.L., and Brew, K. (1975) Adv. Enzymol. 43, 411-490 
40. Thiem, J., and Wiemann, T. (1991) Angew. Chem. Intl. Ed. Engl. 30, 1163-1164

41 Thiem, J., and Wiemann, (1992) Synthesis 141-145

42. Wong, C.-H., Wang, R., and Ichikawa, Y. (1992) J. Org. Chem. 57, 4343-4344

43. Srivastava, G., Hindsgaul, O., and Palcic, M. M. (1993) Carbohydr. Res. 245, 137-144

44. Palcic, M.M., and Hindsgaul, O. (1991) Glycobiology 1, 205-209

45. Do, K.-Y., Do, S.-I., and Cummings, R.D. (1995) J. Biol. Chem. 270, 18447-18451

46. Chiu, M.H., Tamura, T., Wahhwa, M.S., and Rice, K. (1994) J. Biol. Chem. 269, 16195-16202

47. Hooper, L.V., Hindsgaul, O., and Baenziger, J.U. (1995) J. Biol. Chem., 270, 16327-16332

48. Hindsgaul, O., Kaur, K.J., Gokhale, U.B., Srivastava, G., Alton, G., and Palcic, M.M. (1991) ACS Symp. Ser. 466, 38-50

49. Berliner, L.J., and Robinson, R.D. (1982) Biochemistry 21, 6340-6343

50. Kodama, H., Kajihara, Y., Endo, T., and Hashimoto, H. (1993) Tetrahedron Lett., 34, 6419-6422

51. Kajihara, Y., Endo, T., Ogasawara, H., Kodama, H., and Hashimoto, H. (1995) Carbohydr. Res. 269, $273-294$

52. Arlt, M., and Hindsgaul, O. (1995) J. Org. Chem. 60, 14-15

53. Andree, P.J., and Berliner, L.J. (1978) Biochim. Biophys. Acta 544, 489- 495

54. Yuasa, H., Hindsgaul, O., and Palcic, M.M. (1992) J. Am. Chem. Soc. 114, 5891-5892

55. Yuasa, H., Palcic, M. M., and Hindsgaul, O. Can. J. Chem., in press

56. Oehrlein, R., Ernst, B., and Berger, E.G. (1992) Carbohydr. Res. 236, 335-338

57. Ichikawa, Y., Lin, Y.-C., Dumas, D.P., Shen, G.-J., Garcia-Junceda,E., Williams, M.A., Bayer, R., Ketcham, K., Walker, L. E., Paulson, J. C., and Wong, C.-H. (1992) J. Am. Chem. Soc. 114, 9283-9298

58. Wong, C.-H., Ichikawa, Y., Krach, T., Gautheron-Le Narvor, C.,Dumas, D.P., and Look, G.C. (1991) J. Am. Chem. Soc. 113, $8137-8145$

59. Nishida, Y., Wiemann, T., Sinnwell, V., and Thiem, J. (1993) J. Am. Chem. Soc. 115, 2536-2537

60. Nishida, Y., Wiemann, T., and Thiem, J. (1992) Tetrahedron Lett. 33, 8043-8046

61. Nishida, Y., Wiemann, T., and Thiem, J (1993) Tetrahedron Lett. 34, 2905-2906

62. Nishimura, S.-I., Lee, K.B., Matsuoka, K., and Lee, Y.C. (1994) Biochem. Biophys. Res. Commun. 199, $249-254$.

63. Matsuoka, K., and Nishimura, S.-I. (1995) Macromolecules 28, 2961-2968

64. Wiemann, T., Taubken, N., Zehavi, U., and Thiem, J. (1994) Carbohydr. Res. 257, C1-C6

65. Kopper, S. (1994) Carbohydr. Res. 265, 161-166

66. Schuster, M., Wang, Wang, P., Paulson, J. C., and Wong, C.-H. (1994) J. Am. Chem. Soc. 116, 1135-1136

67. Meldal, M., Auzanneau, F.-I., Hindsgaul, O., and Palcic, M. M. (1994) J. Chem. Soc., Chem. Commun. 1849-1850

68. Srivastava, G., Alton, G., and Hindsgaul, O. (1990) Carbohydr. Res. 207, 259-276

69. Kaur, K. J., Alton, G., and Hindsgaul, O. (1991) Carbohydr. Res. 210, 145-153

70. Sarkar, M., Hull, E., Nishikawa, Y., Simpson, R.J., Moritz, R.L., Dunn, R., and Schachter, H. (1991) Proc. Natl. Acad. Sci. USA 88, 234-238

71. Kumar, R., Yang, J., Larsen, R.D., and Stanley, P. (1990) Proc. Natl. Acad. Sci. USA 87, 9948-9952

72. Kumar, R., Yang, J., Eddy, R.L., Byers, M. G., Shows, T. B., and Stanley, P. (1992) Glycobiology 2, 383-393

73. Nishiu, J., Kioka, N., Fukada, T., Sakai, H., and Komano, T. (1995) Biosci. Biotech. Biochem. (1995) 59, $1750-1752$

74. Kaur K.J., and Hindsgaul, O. (1991) Glycoconj. J. 8, 90-94

75. Macher, B.A., Holmes, E.H., Swiedler, S.J., Stults, C.L.M., and Srnka, C.A. (1991) Glycobiology 1, 577-584

76. Mollicone, R., Reguigne, I., Fletcher, A., Aziz, A., Rustam, M., Weston, B. W., Kelly, R. J., Lowe, J. B., and Oriol, R. (1994) J. Biol. Chem. 269, 12662-12671

77. Palcic, M. M. (1994) Methods Enzymol. 230, 300-316

78. Gokhale, U.B., Hindsgaul, O., and Palcic, M.M. (1990) Can. J. Chem. 68, 1063-1071

79. Stangier, K., Palcic, M.M., and Thiem, J. (1994) Abstract B 2.70 of the XVII th International Carbohydrate Symposium, Ottawa Canada July $17-22$

80. Srivastava, G, Kaur, K. J., Hindsgaul, O., and Palcic, M. M. (1992) J. Biol. Chem. 267, 22356-22361

81. Hallgren, C., and Hindsgaul, O. (1995) J. Carbohydr. Chem. 14, 453-464

82. Nikrad, P.V., Kashem, M.A., Wlasichuk, K.B., Alton, G., and Venot, A.P. (1993) Carbohydr. Res. 250, 145-160

83. Bergwerff, A.A., van Kuik, J.A., Schiphorst, W.E.C.M., Koeleman, C.A.M., van den Eijnden, D.H., Kamerling, J.P., and Vliegenthart, J.F. G. (1993) FEBS Lett. 334, 133-138

84. Higa, H.H., and Paulson, J.C. (1985) J. Biol. Chem. 260, 8838-8849

85. Gross, H.J., Bunsch, A., Paulson, J.C., and Brossmer, R. (1987) Eur. J. Biochem. 168, 595-602

86. Gross, H.J., Rose, U., Krause, J. M., Paulson, J.C., Schmid, K., Feeney, R.E., and Brossmer, R. (1989) Biochemistry 28, 7386-7392

87. Gross, H.J., and Brossmer, R. (1988) Eur. J. Biochem. 177, 583-589

88. Gross, H.J., and Brossmer, R. (1987) Glycoconj. J. 4, 145-156

89. Sticher, U., Gross, H.J., and Brossmer, R. (1991) Glycoconj. J. 8, 45-54

90. Ito, Y., Gaudino, J.J., and Paulson J. C. (1993) Pure Appl. Chem. 65, 753-762

Received on October 16,1995, accepted on October 20, 1995 